\title{
Features of housing sanation in the historical architectural environment
}

\author{
Kateryna Danko \\ e-mail:smaz1981kate@gmail.com \\ Architectural faculty, department of drawing and painting, \\ Kyiv National University of Construction and Architecture
}

\section{Kashchenko Tetyana}

e-mail:kash-ta@ukr.net

Associated prof., Department of Architectural Design of Civil Buildings and Structures, Kyiv National University of Construction and Architecture

\begin{abstract}
In Ukraine, one of the main problems in the field of architecture and construction is an outdated housing stock with low energy efficiency indicators. The total housing stock of Ukraine is 1031.7 million $\mathrm{m}^{2}$, of which more than 4.8 million $\mathrm{m}^{2}$ is an outdated and emergency stock, $11 \%$ of residential buildings need repairing, and $9 \%$ - reconstruction. Its significant part (72 million $\mathrm{m}^{2}$ or $23 \%$ ) is morally outdated buildings of the first mass series of $1950-1960$, which have a number of structural deficiencies and do not fit to current norms [11].

Most of the existing housing are in the historical environment, therefore, in addition to traditional approaches to the formation of energy-efficient housing, there are special approaches associated with a number of restrictions on the compositional, stylistic, and coloristic integrity to the architectural environment whith increasing energy efficiency of housing. This problem needs to be solved in a complex way, using thermo-modernization, thermo-reconstruction, sanation. An analysis of these approaches has shown that sanationis the most effective, as measures for the rehabilitation of multi-apartment buildings allow to increase energy efficiency of housing and preserve historical architectural heritage within the existing housing stock.
\end{abstract}

Key words: sanations, housing, architectural environment, energy efficiency.

\section{Survey of research}

Problems of energy saving in architecture and construction in Ukraine were researched by: O.V. Bumazhenko, M.O. Brodsky and O.M. Pechenyk, who study the influence of city-planning methods on the change of architectural environment in order to reduce the negative climatic influences and increase the level of energy saving of urban development; O.V. Serhiychuk, which modeled the physical processes in optimizing the form of energy-efficient buildings; V.L. Martynov, who explores the geometric parameters of individual components of energy-efficient buildings; T.O. Kashchenko, who deals with the optimization of the form of energy-efficient homes; L.O. Shuldan, who investigated the problem of building energy-efficient buildings, in particular schools, I.P. Kozyatnik, L.P. Khokhlova, G.F. Chernykh, N.V. Shilkin, G.G. Farenyuk and others.

The stylistic solution and the harmonious introduction of new housing in the historical environment are considered in the works of A. Ikonnikov, O. Becker, V. Vechersky, E. Vozdvynsky, V. Lavrov, S. Regame, T. Tovstenko, T. Cherkasova, and others. From abroad, examples of rehabilitation of existing housing in Germany, the Czech Republic, Latvia, Estonia, Republic of Poland were analyzed. In Germany in 1990 a state program of sanation of dwelling houses was established, the main task of which was - "healing" of houses built from prefabricated panels. It included repairing of the roof, supporting elements of the building, increasing of thermal insulation, introduction of heating systems with individual regulation of heat supply, improvement of adjacent territories, 
etc. In Poland, too, the problem of outdated housing began to be dealt with in the 90 's of the twentieth century. By the moment, $50 \%$ of the apartment dwelling has been renovated - they consume less energy due to constructive and engineering measures, and also have a modern attractive appearance due to architectural, planning and stylistic-compositional measures. Examples of cities where the massive rehabilitation dwellings were: Gdynia, Katowice, Wroclaw, Warsaw [1,2].

\section{Scientific methods}

Studying the problem of an outdated housing stock and its sanation were applied method of retrospective analysis, the method of morphological analysis, the method of compositional analysis, the method of stylistic analysis, the method of artistic and aesthetic analysis, the method of conceptual analysis of the formation. When working with outdated housing stock, there are the problems of increasing energy efficiency of housing and the problem of preserving the historical architectural environment where the existing housings are located. To solve these problems, it was proposed to apply: thermo-modernization, thermo-reconstruction, sanation.

Thermo-modernization is a complex of constructive means for the thermal insulation of the building's shell (external walls of the building, basement, roof renovation, replacement and repair of windows, balcony blocks and entrance doors to the building) in order to bring its energy efficiency indicators in line with modern requirements without changing the engineering equipment, a typical design solution and a three-dimensional compositional solution of the building, but with partial re-planning and restoration of the operational qualities of the building.

Thermo-reconstruction is a complex of repair and construction works related to the increase of thermal engineering indicators of fencing constructions, rebuilding of the building and its engineering equipment with the change of the structure of apartments without changeingthe building volume or with achangeing of volume of the building at the expense of the annex, a multi-storey superstructure or an extension of the building to improve the energy efficiency of the building.

Sanation [10] - besides increasing energy efficiency by constructive, engineering and architectural-planning methods, considering ecological, economic, social, psychological, aesthetic aspects, improving the microclimate, improving the comfort level of individual apartments and the whole building, improving the volume-spatial house compositions and surrounding buildings. The sanition of the living environment is carried out in order to obtain housing with improved living conditions that meets all modern energy efficiency standards and takes into account the environment. It is the best method for providing energy efficiency to residential buildings.

\section{Research of existing housing}

For legislative regulation of energy efficiency issues in Ukraine, exist the Law of Ukraine "Energy saving", "The complex reconstruction of neighborhoods (districts) of an outdated housing stock", "Energy efficiency of buildings", which determine the legal, socio-economic and organizational principles of activities in the field of energy efficiency buildings and aimed at reducing energy consumption in buildings [4]. In order to effectively implement energy-efficient construction solutions in Ukraine, the "warm loans" program was adopted as one of the mechanisms for ensuring energy efficiency. The program is developed for co-owners of multi-dwelling housing (ACMHs). ACMHs - are a form of management of residential buildings. The movement for the creation of ACMHs began in Ukraine about 10 years ago and in some cities it covers up to $90 \%$ of the housing stock. In Poltava, in particular, the creation of ACMHs began 3 years ago, and currently, ACMHs cover only $10 \%$ of residential buildings, but their creation is growing rapidly. Also, IQ Energy program has been introduced in line with European standards, a financial instrument for promoting energy efficiency improvements in the residential sector of Ukraine [5]. The rehabilitation of multi-apartment residential buildings is a promising way of solving the energy efficiency problem of residential development and allows to prolong the life cycle of buildings, improve the quality of housing, improve the quality of engineering equipment, increase their energy efficiency, operational reliability, durability, and save the historical environment of the central parts of Ukrainian cities. 
To implement sanation in the historical environment, it is first necessary to investigate the types, styles, construction periods, constructions and materials of buildings subject for rehabilitation. In this article is presented an analysis of existing housing stock, means aimed at increasing energy efficiency, energy efficiency of buildings during rehabilitation are presented. Housing stock for periods of construction, the prevailing style can be divided as follows:

1. XVII century - XVIII century. The prevailing style is the Baroque, in particular Mazepa Baroque. The architecture of this style has a high aesthetic value. Examples of baroque houses are houses and mansions of the nobility.

2. The middle of the XVIII century, The middle of the XIX century. The prevailing style is classicism. Classicism has a high aesthetic value, and is widely used in the architecture of residential buildings, both historical and modern.

3. The beginning of the XX century. The prevailing style is modern or Art Nouveau, including the European Modern, Ukrainian Art Nouveau. The European Art Nouveau is distinguished by the bright artistic expressiveness of the image of the building. In the facade decoration there are almost no straight lines and sharp corners, natural bends of lines, resembling images of nature are used.

4. The end of the 1920s - the mid-1950s. Pre-war Soviet constructivism and postwar Soviet style - neoclassicism. Pre-war constructivism is characterized by rigor, geometry, concise forms and monolithic appearance.

The post-Soviet style - neoclassicism can be divided into two subtypes - erected by individual projects for the head staf"nomenklature" and typical projectsfor the workers. "Nomenclature" buildings stand out from the background of a high ground floor (sometimes with a colonnade), bright décor, an elevated surface (more than 5 floors). Houses have large halls with 2-4 apartments on the floor. The facades of the buildings are plastered and decorated with stucco decoration. In typical designed buildings was the utilitarian architecture. There is almost no vivid decoror image on the facades. They are made of red or silica brick or plastered. The number of storeys of such buildings does not exceed 5 floors. The height of the floor of the buildings is 3-4 m, brick walls in thickness from 0,65 m and more, wide entrances, wide stairs. On one floor situated 2-4 apartments with separate bathrooms and separate rubbish pipelines.

5. The post-war period of 1955-1990. This kind of housing were basically a massive brick houses built by typical projects. On the city periphery were built low-rise buildings, in the central regions there was a mass introduction of prefabricated hight-rise buildings (block, panels), mass implementation of standard projects. Such reforms in the field of architecture and construction allowed to overcome the growing crisis in housing construction and to return the status of a style-making trend on a global scale to the Soviet architecture [6]. The first designs of the facades of blocks and large-panel houses were solved with the help of the following artistic-compositional techniques: decoration of blocks in the form of large quadrants, illusory cutting of blocks into small elements ("diamond rust), two-row cutting of a wall with decoration of blocks, pitched roofs. But over time, the architecture of residential buildings of this style was reduced due to the prevalence of economic criteria. Compositional solutions were optimized according to the rationality and utilitarianism: the replacement of pitched roofs to the flat, the refusal of the facade decoration, reducing the height of floors, reducing the area of support facilities, the transit rooms. The buildings were built with a small reserve of strength and some of disadvantages: a small living space, a small height of rooms $(2.5 \mathrm{~m})$, small kitchens and corridors, transit rooms and combined bathrooms.

At the same time, prefabricated panel houses appeared (1950-90). This group includes panel houses built in the previous period, typical panel houses, improved typical Soviet panel buildings and panel houses of the 1990s from reinforced concrete or expanded clay concrete. All these buildings present mass housing from inexpensive materials, to the advantages of which can be attributed the high quality of individual panels of exterior walls with possible decoration (in factory conditions) with different mosaics, tiles, etc. The disadvantages of this technology include the presence of joints between the panels, which potentially can form heat bridges. The buildings of this group were built up from 3 to 22 floors, had walls with insufficient resistance to heat transfer, four or more apartments on the floor, the height of rooms is $2.5-2.75 \mathrm{~m}$.

6. End of XX-beginning of XXI century. The modern stage of the formation of the architecture of the living environment. Modern buildings are being built according to typical projects and appear a lot of buildings built according to original projects with individual planning. The architectural stylistic solution of buildings 
varies from ultramodern to styling to historic architecture. For the historical styling is used the main artistic and compositional techniques of those historical above-mentioned styles, which have the greatest influence in this environment. The prevailing height of modern houses is from 4 to 25 floors, the height of the floor is $3-3,3 \mathrm{~m}$, and the area of apartments is from $18 \mathrm{~m}^{2}$ to $100 \mathrm{~m}^{2}$ and more. These buildings have modern communications, the necessary infrastructure for life, autonomous utilities and services.

The analyzed housing development of historical cities of Ukraine has shown that residential buildings of the $20^{\text {th }}$ and $21^{\text {st }}$ centuries dominated by typical projects and buildings with individual planningfrom the last decades, and examples of buildings of the $19^{\text {th }}$ and $18^{\text {th }}$ centuries are less common.

\section{Analysis of measures by enhancing energy efficiency of existing housing}

Depending on the time period, location, technical condition, historical value of the building and the desired work result, it is selected a list of possible ways to improve the energy efficiency of the building - thermo-modernization, thermo-reconstruction, sanation. The thermodernization of residential buildings without changing the building volume does not require significant material costs and is $25-40 \%$ of the restored value of a residential building, with a change in the structure of apartments $-35-50 \%$. The calculations show that when the sanation that the floor addition significantly increases efficiency of the solutions. Thus, in case of mansard floors addition, the cost of work does not exceed $60-65 \%$ of the new construction, and the construction of additional floors reduces the cost per unit area by $25-30 \%$. When performing works on the thermoregulation of residential buildings, special attention should be paid to improving operational characteristics and, in the first place, reducing energy consumption by increasing the thermalinsulation parameters of fencing structures, introducing a system for automatic regulation of heat consumption and its accounting, as well as utilization of heat of ventilation emissions. In carrying out the rehabilitation of residential buildings in order to provide regulatory requirements for energy efficiency, it is necessary to take into account the features of city-planning and architectural composition of the surrounding building, characteristic composite features of the prevailing styles, as well as the degree of historical value of the territory. The main feature of the sanation is that the buildings are considered as part of the historically formed environment with its structure, regularities, color, and other characteristics. The sanation covers a wide range of measures to bring the indicators of comfort of a residential building up to standard ones. The rehabilitation can be carried out as well as with a change in the volume of the building (add-on glasing of balconies and loggias, re-equipment of the cold attic), and without changing the volume (insulation of opaque fencing structures, replacement of transparent fencing structures, repair or replacement of communications, water supply systems and drainage, ventilation and air conditioning, the use of energy-generating units for the renewable energy sources). In the historical context, it is necessary to take into account compositional constraints and to be guided by the principle of harmonization of the environment, to conduct sanation in whole using such measures as conservation, restoration, and ongoing repairs. The rehabilitation includes various approaches to improving the overall level of comfort and providing buildings with a standard energy efficiency indicator in particular, and cares about preserving the historical environment.

The study of the technical condition of residential buildings of different time periods of construction has shown that classical buildings are in a satisfactory technical condition. During rehabilitation, a minimum number of energy-saving measures are required. Buildings in the Art Nouveau style also have a satisfactory technical condition, while the sanationneeds a minimum amount of energy-saving measures. Neoclassical residential buildings have a satisfactory technical condition, there are slight deviations from the regulatory requirements for heat engineering indicators. Typical building of 1950-1980 are in the worst technical condition among considered housing buildings and require carrying out of urgent complex measures on sanationand increase their energy-saving properties. The most widespread series of mass housing construction in Ukraine are 1-438 and $1-480$ series [8], as well as buildings with large-frame frameless, transverse bearing walls of the series 1-464; large-panel buildings with an internal full or incomplete frame of a series 1-335; frameless buildings with walls of artificial materials or large blocks with three longitudinal bearing walls of series 1-434, 1-447 ("three-wall" buildings) [9]. The main disadvantages of these houses are planning solutions with small area of kitchens, combined bathrooms, inadequate area of the anterooms, passage rooms, technical and technological issues of construction, deficiencies in construction, careless maintenance of buildings, unsatisfactory operating 
conditions (external enclosing structures, hydro, - thermal insulation, joints of walls with window blocks, glazing of window blocks, constructions of balconies, canopies above entrances, roofs), and as a result, the losses more than $70 \%$ of thermal energy in buildings.

\section{Research of the existing housing foundation of the city of Poltava}

In the central part of the city of Poltava predominate houses of the nineteenth and first half of the twentieth century, which have a high historical value. Their characteristic features are:

Typical form of multi-apartment buildingsare:

- "point" (square in plan);

the corner.

Typical floors numbers of multi-apartment housesare:

- low-rise (1-2 floors);

- intermediate floors (3-5 floors);

multistory (7 floors).

Typical orientation of apartment buildingsin the centerof Poltava are:

- square in the plan buildings are located at an angle of $45^{\circ}$ to the axis of South-North; - meridional (with a deviation from the axis of South-North to $30^{\circ}$ );

- latitudinal buildings (with a deviation from the axis of South-North to $30^{\circ}$ );

- corner buildings with an outer angle to the South, North, East or West.

Typical urban placement of quarters in the center of Poltava are:

- perimeter buildings;

- multi-storey perimeter buildings with central passage;

- one-sided perimeter variety of buildings;

- homestead buildings.

Conducting research in the city of Poltava showed that the following buildings presented in Table 1 are typical for the city Poltava (used materials of the site http://domofoto.ru/cities/119/):

Table 1. Typical dwelling houses in the city of Poltava.

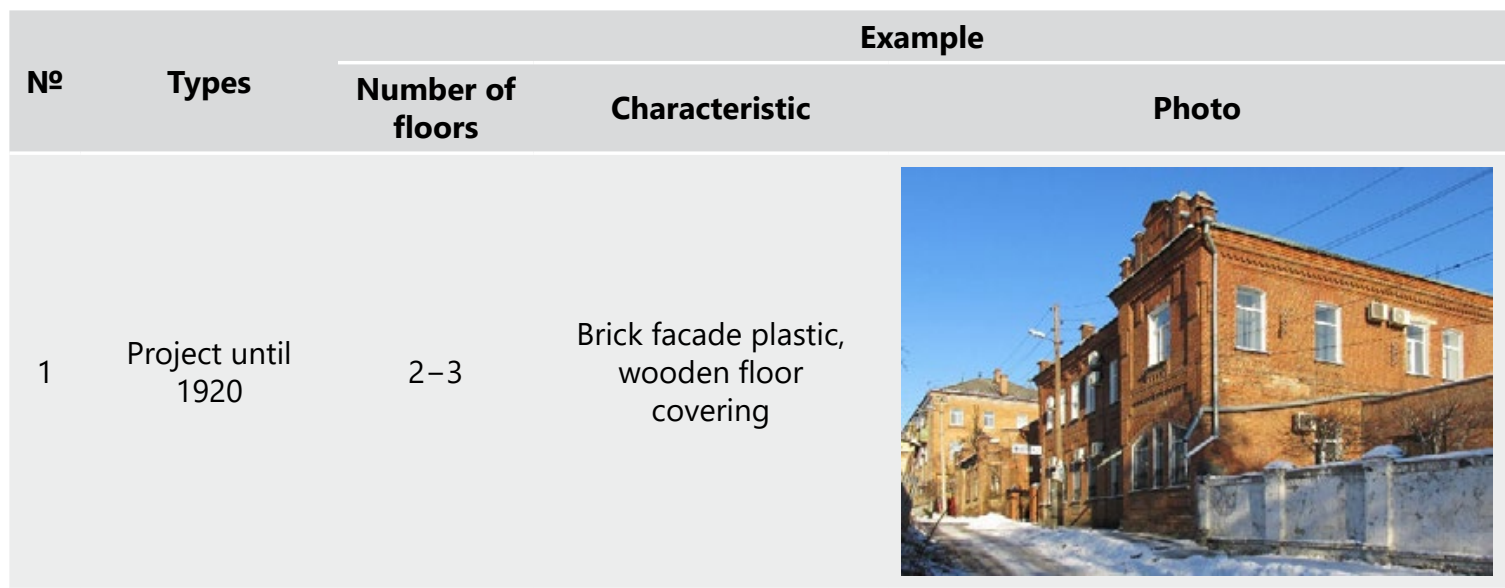




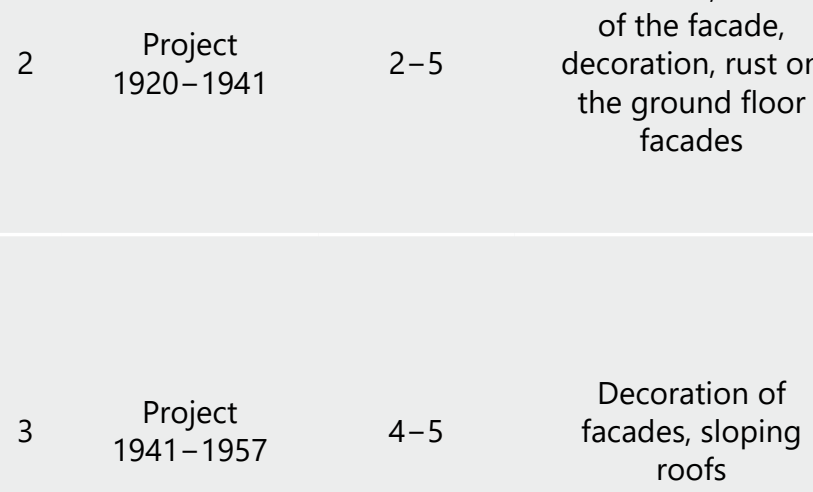

Typical projects and projects

4 reused for a series of brick houses

$5 \quad$ Block houses

$6 \quad 1-439 A-40$

124-87-107

7 Panel house of mass series
Brick walls, details of the facade, decoration, rust on the ground floor

Brick houses by typical projects

Optimization of compositional solutions, subordination for the rationality and utilitarianism: flat roofs, lack of facade decoration, transit rooms. small living space, low room height $(2.5 \mathrm{~m})$, small kitchen, combined bathrooms.
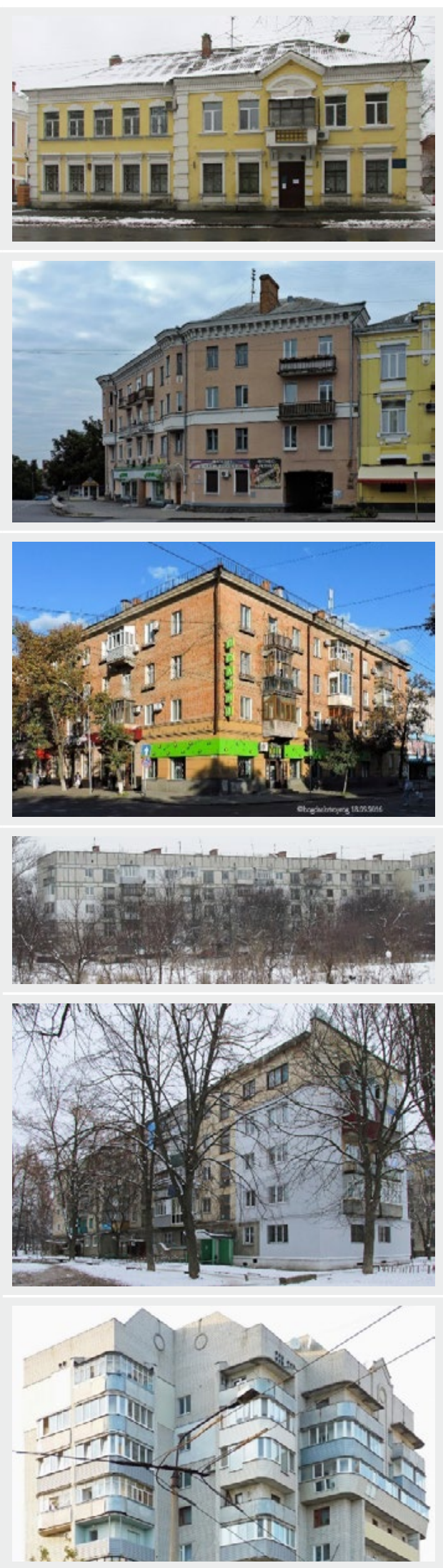


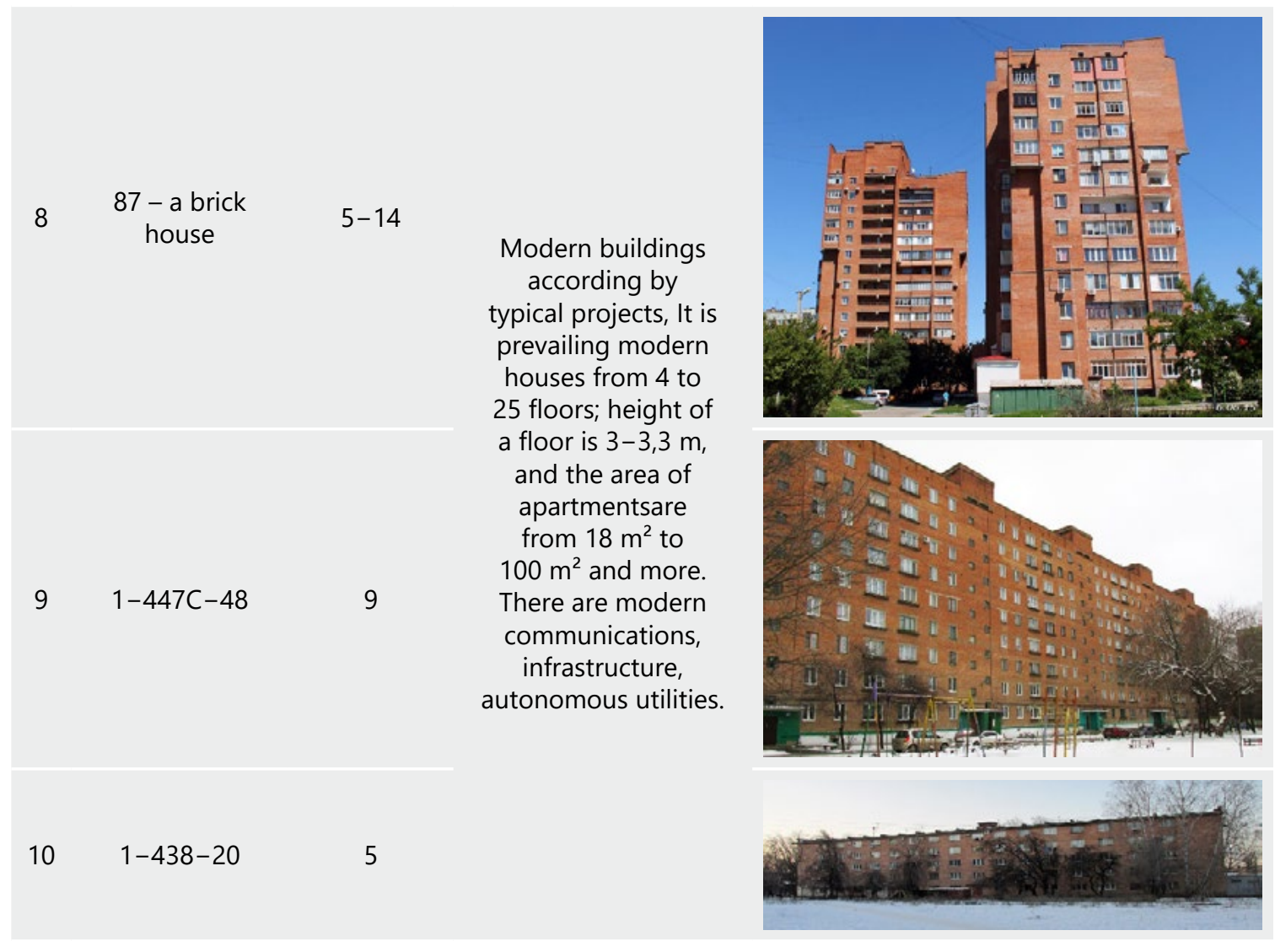

On the periphery of the city dominating buildings which are built on typical projects. These are block, panel, brick houses from 5 to 14 floors. A wide range of sanation means can be applied to massive building houses. Houses built before 1957 need an individual approach with the choice of necessary sanation means that do not destroy the existing urban planning, architectural, planning, compositional and stylistic structure. Architectural techniques include expansion of the building towards the yard, floor addition of the attic floor, change of the planning solution of the house - placing stairs inside the house (with the upper natural light), temperature zoning of apartments (with a thermal core and a buffer zones), insulation of enclosing structures, replacement of engineering communications. Modern residential buildings located both in the central part and in the peripheral districts of the city of Poltava have a satisfactory technical condition, may have slight deviations from the regulatory requirements for heat engineering indicators due to the recent updating of the regulatory framework for energy conservation requirements [3].

\section{Conclusions}

Sanation for the providing a normative indicator of energy efficiency in existing buildings presents a wide range of posibilities. In the absence of a historical environment limitation the shape of the building, its planning structure, materials, engineering and technical equipment may vary. During the housing sanation in the historical environment next requirements are taken into account: stylistic, compositional, rhythm-metric features of the facades of existing buildings; the silhouette of the building; the presence of architectural monuments and their influence on the surrounding buildings; the scale, dimensions, configuration; the surface of the existing buildings; the size of the house space; ventilation and shadowing of the territory of the yard and on the basis of the research the sanitation measures are selected. The renovation requires about $30 \%$ of the cost compared with the new construction, so it is economically more profitable than building a new home. At 
the same time, the cost of saving energy for heating during the renovation of the housing stock is up to $85 \%$. A wide range of sanation methods allows it to be used in the conditions of an existing housing stock and is relevant, promising and cost-effective. Sanation provides broad opportunities for realization in the conditions of existing development, providing energy resources saving and increasing the comfort of living in residential buildings, including taking into account the researches carried out on the historical environment for each particular city with its architectural, planning, spatial and stylistic-compositional feachers.

\section{References}

[1] Agata Warchalska-Troll. Progress in the rehabilitation of large residential estates in Katowice (Poland). - Hungarian Geographical Bulletin 62 (1) (2013) 102-112.

[2] Michal Dmitruk. Problemy budownictwa wielkoplytowego $z$ lat siedemdziesiątych XX wieku I sposoby ich rozwiazania na przykladie z polski I innych krajow europejskich. - TEKA Architectural Comission, Urban Studies and Visual Studies. Tom XI / 1-4. Lublin 2015. p.16-24.

[3] Avdiyenko O.P. Reconstruction of housing at the present stage / O.P. Avdiyenko // Reconstruction of housing. -2007. - Issue 8. - P.13-18.

[4] Electronic resource. Access mode https://www.gov.ua/

[5] Electronic resource. Access mode http://www.iqenergy.org.ua/ru

[6] Electronic resource. S.O.Khan-Magomedov, Khrushchevki - good or evil ... http://dwg.ru/pub/26

[7] Malyarenko V.A., Orlova N.A. The state and ways of renovation of the housing stock of past years. Energy saving • Energy • Energy audit №9 (91) 2011. - Kharkov.

[8] Onischuk G.I. Technical aspects of the reconstruction of residential buildings in Ukraine / G.I.Onishchuk // Reconstruction of housing. -2012 , vol. 13.

[9] Pylypenko V. Features of reconstruction of residential areas of industrial development of the last century. September 16, 2005 [Electronic resource]. Access mode: http://ais.by/story/560

[10] Recommendations for the selection of progressive architectural and technical solutions for the reconstruction of residential buildings of different design systems. - Kiev Nora Print, 2001.- 262p. 